\title{
Crises of the Global Finance: Politics of Monetary Authorities (1994-2014)
}

\author{
Viacheslav M. Shavshukov ${ }^{1} \&$ Natalya A. Zhuravleva ${ }^{2}$ \\ ${ }^{1}$ Saint Petersburg State University, Russia \\ ${ }^{2}$ Petersburg State Transport University, Russia \\ Correspondence: Viacheslav M. Shavshukov, Saint Petersburg State University, 62 Chaikovskogo Str., 191123 \\ St. Petersburg, Russia. E-mail: shavshukov@rambler.ru
}

Received: September 29, 2014 Accepted: October 16, $2014 \quad$ Online Published: March 27, 2015

doi:10.5539/ass.v11n7p376 URL: http://dx.doi.org/10.5539/ass.v11n7p376

\begin{abstract}
Since the beginning of the 80s.of twentieth century, a global financial and economic environment system was formed, and one sign of which were the crises of the global finance. Anti-crisis measures of the monetary authorities are a combination of Keynesian and monetarist prescriptions. The first are nationalization, purchase by state (or regional financial institutions - RFI) distressed assets, the maintenance of employment and demand, social programs, state spending on High-tech. The second are tax breaks, reducing rates of discount and rates of interest, avoiding inflation by controlling the money supply.
\end{abstract}

Keywords: Crises in Mexico, Southeast Asian countries, the Russian default, the global crisis of 2008-2009, The Eurozone crisis, the patterns of global finance crises, anti-crisis measures of the monetary authorities and the G20

\section{Introduction}

Since the beginning of the 80 s of the twentieth century, a global financial and economic environment system was formed, one sign of which were the crises of the global finance. Their cradle are the national economy different in different periods (Mexico-94, South Korea-97, US-08); classical nature is the imbalance of the internal market. In a global economy "the waves of the financial tsunami" overwhelm other economies. Anti-crisis measures of the monetary authorities are a combination of Keynesian and monetarist prescriptions. The first are nationalization, purchase by state (or regional financial institutions - RFI) distressed assets, the maintenance of employment and demand, social programs, state spending on High-tech. The second are tax breaks, reducing rates of discount and rates of interest, avoiding inflation by controlling the money supply.

The global crisis of 2008-2009 and follow-up to the 2014 the recession (especially in the EU) differentiated superficial reasons and the profound nature of the crises, put the world on to the necessity of the solidarity actions of G20, solving the problems of civilization and the rapid transition to a new technological order.

This article focuses on the analysis of the anti-crisis measures of the monetary authorities in the global finance crisis (1994-2014).

\section{Methodology}

The research is based on the systematization of the laws of the first crisis of the global economy, the analysis of new phenomena and the deep nature of the global crisis and post-crisis recession in the EU. Complex analysis methods (information gathering, analysis and synthesis) and make it possible to justify and to submit to testing in the scientific community the following hypothesis. In global economic environment the national economics are its segment, they are affected by external factors - international market trends, inflow / outflow of foreign investment. They are affected to both internal cycling of the reproduction process, and the international. In a global economy crises arise in some of its weakest link and as the waves overflow other economies. Nevertheless, the cradle of the crises is the disbalanced national economy, the external factor (withdrawal of the foreign investor) exacerbates their course. Crises of the global economy (1994-2004 yy.) have common patterns and country specificities. We believe that the global crisis of 2008-2009 and subsequent creeping recession (2010-2014 yy.) are not only a superficial reasons (mortgage collapse and the crisis of the financial system of the United States), but also the profound nature - the transition to a new type of production technology. The global economic environment, the 
patterns of global finance crisis make the necessity of joint actions of the monetary authorities of G20 and the content of crisis programs. Their analysis suggests that the programs are a combination of Keynesian and monetarist prescriptions contain general and special, use various anti-crisis financial instruments (from simple to complex).

\section{Results}

\subsection{Laws of the First Crises of the Global Finance}

The first crises of global finance (Mexico-1994, Southeast Asia-1997, Russia, the Czech Republic, the Baltic countries-1998, Turkey-1999, Argentina, Brazil - 1999-2000) were rather regional than global. However, it was a "global test pen" contagion corridors were wide and far enough (waves of the crisis in 1997 in Southeast Asian countries quickly sunk to the Russian financial markets. Weak banking system shaken, but resisted), the laws of the global crisis were worked out, which fully manifested in the crisis of 2008-2009.

Common causes of the crises of the 1990s. The reasons have always been internal, external factors (actions of TNCs, TNB, mutual funds) aggravated the macroeconomic situation. Inflationary pressure worked to the crisis (increase in domestic stock prices and property caused the internal deficit) and balance of payments deficit. Artificial hold of central banks in the exchange rates within the exchange rate band and linking to an anchor currency does not provide rate stability and led to the devaluation. The opacity of the financial sector, the practice of the risky lending to the government, the crisis of confidence to the national banks have led to underestimation of a risk by foreign investors and credit rating agencies and the overvaluation of profitability of local financial assets. Under these conditions, "the global investor" in carrying out its obligations to investors and shareholders, was forced to withdraw assets nominated in the national currency, which brings down its exchange rate stability and contributed to the devaluation.

Along with the common causes of crises in each country there were specific.

In the 80 -ies of the twentieth century many developing countries have adopted various programs to modernize the national economy. Their key element was to attract foreign capital, technology, management. Foreign investment has become a factor, on the one hand, of the economic growth, emerging from the crisis, on the other - the deterioration of the situation during recessions.

The example of Mexico is significant. In the 1988-1994 the Mexican government began actively attract foreign investment. But the imbalance of trade balance (deficit in 1994 was $8.2 \%$ of GDP) and financial account resulted to the devaluation of the peso by $27 \%$, the withdrawal from the country of foreign capital, the crisis of the banking system.

The monetary authorities took various anti-crisis measures, which, together with the United States loan of \$20 billion allowed in 1995 to reverse the crisis processes (production decline began to slow). But apparently, the decisive factor in an overcoming of the crisis was Mexico's accession to NAFTA, which established a regime of free trade, movement of capital and labor, foreign trade procedures were simplified. Resetting the customs duties, the liberalization of legal restrictions on the activities of American and Canadian banks in Mexico, investment attraction, the protection of intellectual property and the rights of investors led to an increase in the volume of trade in the 1993-2012 by 506\%, Mexico's exports grew by $25 \%$, the additional growth of GDP as of 2003 was $0.8 \%$, while GDP per capita increased from 1996 to 2009 at 2.06 times.

Crisis in Southeast Asian countries in 1997. In summer and autumn of 1997 in Southeast Asian countries experienced a sharp and strong pressure on the foreign exchange market. In Thailand and Indonesia it has led not only to a reduction of foreign exchange reserves, and to a change in monetary policy of the countries. Government refused from pegging the national currency and translated pieces of foreign exchange in free market swimming. In South Korea the depreciation of the vons has led to a precipitous drop in stock prices.

Common causes of the crisis are: inflationary pressure (swelling property prices and stocks caused internal deficiency); artificial retention rate, overvaluation of profitability of local financial assets; deficit of balance of payments.

Thus, the causes of the crisis - internal (trade balance deficit, revaluation of financial assets, bad loans, currency corridor, lack of reserves), kindling hearth - an external factor (investors sought to get rid of overvalued securities, began to withdraw capital, increased the pressure on the foreign exchange market).

Crisis in Southeast Asia comes amid stock boom of 90s., which led to an overestimation of both developing and developed markets. As an important factor fueling this boom, were foreign investments. This has led to an 
increase in current account deficit of countries, which reflects the difference between how much a country invests and how many saves because of the expense of capital imports.

Especially the developing countries experienced the pressure of the crisis: there was an increase in the money market spreads and premiums on foreign exchange; decreased growth rate from $6.0 \%$ to $5.75 \%$; GDP declined in India, weakened rupee; Brazil and Argentina had a preventive measure: increased reserves and spreads on sovereign debt, which is slightly reduced the rate of inflation. Russia, Czech Republic, Estonia, Ukraine experienced a strong pressure of the crisis that resulted from the balance of payments deficit, weak tax collection. China is the only country from the group of developing countries - kept the "immunity" as pursued a policy of attracting direct foreign investment, limits of financial speculation, creating substantial foreign exchange reserves, positive current account balance, a weak yuan.

International capital markets have also experienced the pressure of the wave of the crisis of Southeast Asia. In the mature capital markets in 1994-1997 there was a reduction of interest rates (as a result of fiscal consolidation, reducing the rate of inflation, increased competition in the international banking market). On the other hand, with the rapid growth of prices in the capital market the United States and investors' expectations of increasing revenue, there was concern about the negative impact on the emerging markets of a possible correction of mature markets.

Globalism of global finance crises is not only a factor of the crisis, but also became the main condition to overcome it. In October - November 1997 the devaluation of the currencies of the countries of Southeast Asia accounted for $30 \%$, the stock indexes in the region fell by $18 \%$, while the leading Western stock exchanges $9-10 \%$, Russia - 16\%, Brazil - 10\%. For global stock indices is not unique synchrony of fluctuations, but also a definite pattern in the fracture of bust / growth indices of global financial centers and developing markets. In the fall of 1997 the gap of indices observed by a coefficient of 2-3 (fall of the DJIA was 4.7\% against of a fall of developing markets indices: Rs 15,67\%, Bovespa - 10,20\%, Hang Seng - 18\%).

In Russia in 1998, the internal weakness of the banking sector - lack of free capital, low liquidity and reliability, poor asset-liability management, foreign exchange and interest rate risks were led to the collapse of the banking system.

\subsection{The Global Financial and Economic Crisis of 2008-2009}

The deep nature of the crisis. Transition to a new technological order, based on the information, "nano", "bio", "green", "blue" energy-saving technologies, genetic engineering, alternative energy sources and other innovative technologies, which is a technological response to the needs of society and the economy, urgent problems of civilization - food, environmental, nuclear and energy security of the mankind.

The world economy has lost former sources of the growth (the average population of the West and emerging markets). Decline in economic growth is a conflict of technologies from XX and XXI centuries. The transition to the new economy is difficult; it is accompanied by structural changes, the flow of capital. Subtle indicators of changes are stock indexes.

The statistical dynamics of the stock markets of the USA in 2000-2009 is the proof of this, showing the correlation indices DJIA and Nasdaq Composite equal to 0.95. This indicates, firstly, on the synchrony of motion in all phases of the cycle in all sectors of the economy of the USA - the traditional and the high-tech. Secondly, it confirms the idea that the High-tech has not yet become an attractive investment for the ground, first of all, a conservative investor. Third, the transition to a new technological order did not reflect in the stock market and it is not currently economically feasible.

Therefore, there are some reasons to believe that the nature of the crisis is twofold: first, the elements of national crisis and the global financial system; secondly, the crisis of monetary model of "mixed economy", based on the technologies of the second half of the twentieth century.

Causes of the global crisis of 2008-2009. If the nature of the processes reflects the underlying fundamental phenomena, so the reasons are superficial. Nature and causes may coincide in time and space. Mortgage crisis in the United States, provoked the crisis of the financial, construction and industrial markets in the United States, followed by the EU, Japan, and developing countries, was the cause of the global crisis. It tragically coincided in time and space (the United States economy is the most nominated to the complete transition to a new technological order) with the crisis processes the conflict of old and new economy.

Crisis response of the global economy. Globalized world economy instantly responded to the crisis in the economy of the USA. There has been a decline in exports of the BRIC countries in the EU and the United States. Export from EU and Japan in the United States decreased. Export of investment goods in China and India 
decreased too. There was a loss of liquidity of the leading financial institutions in the EU zone, the UK, Switzerland, Japan, the BRIC on average of $10-30 \%$, a decline in global industrial production by $10-35 \%$ and reduce GDP by $1-10 \%$. In all countries, there was an increase in unemployment in the $6-15 \%$ (average $10 \%$ ). Stock indices reacted by the fall on $10-40 \%$. There was an increase of the state internal and external debt to GDP ratio from $60 \%$ (USA, Germany and Canada) to $170 \%$ (Japan). Most countries have not escaped the growing state budget deficit to $10 \%$ of GDP. TNC and TNB started to remove assets from the investing markets. There has been a run of the Central Bank, business and markets into the "dollar" harbor and depreciation of the euro, pound sterling, yen, Swiss franc, yuan, ruble, rupee, real against the dollar. And finally, in the developed markets a dangerous trend of deflation has formed, and in emerging - the inflation.

Anti-crisis measures in the G20 context to the global financial and economic crisis of 2008-2009: reason of the solidarity actions, development of anti-crisis measures.

In the global economy, the global financial and economic crisis of 2008-2009 for the first time in history demanded solidarity action by governments and monetary authorities of G20, producing $90 \%$ of world GDP.

IMF members sent to the rescue of the financial sector of the world economy $\$ 11.4$ trillion, including in the form of capital \$ 1.56 trillion, guarantees $\$ 4.64$ trillion, through the acquisition of assets $-\$ 5.21$ trillion. Developed countries were sent to the anti-crisis program of $\$ 9.2$ trillion. Developing - $\$ 1.6$ trillion, G20 - 2\% of GDP, including \$ 4.6 trillion on the government guarantees on debt; $\$ 2.5$ trillion to maintain the liquidity of national banking systems; $\$ 1.9$ trillion to purchase troubled assets; $\$ 1.1$ trillion on strengthening of the capital base. (World retribution for the crisis, 2009). The central banks of G7 (based on the basic agreement in 1985) agreed on currency intervention in the Forex market to support the dollar, because it is the currency in the present moment has no alternative in backup for international liquidity and gold reserves, as well as a de facto primary (44\%) in international payments. Similarly, at the Summit of G7 finance ministers and the ECB 18 March 2011 joint action in the foreign exchange market to support the yen after the double tragedy in Japan were agreed after floods and nuclear power plant accident in Fukushima. (Treasury of UK, 2013).

For monetary authorities and financial center in the periphery the main financial solidarity actions were providing financial and economic stability (in this case, does not refer to a specific financial center, such as London, Frankfurt-am-Main, Zurich. We share in the global finance on the "financial center" and "financial periphery": the first refers to the financial centers of the West, the second - to the financial markets of developing countries).

Direction of anti-crisis measures were agreed at the G20 summit in New York and London, and was represented by a combination of Keynesian and monetarist prescriptions.

The first direction: Public investment in creation and renewal of infrastructure of national economies (construction and repair of roads, housing, schools), state support of the labor market.

The second direction: Stimulating consumer demand through subsidies, tax incentives, reduction in base rates of interest on loans and bank deposits (to encourage, on the one hand, drafts and purchases, on the other - reducing savings) to stimulate demand in key markets; stimulating domestic demand.

The third direction: Reforming (modernization) of the system of global finance, including institutions and instruments. At the G20 summit was reached an important agreement to increase ICF resources (from $\$ 430$ billion to $\$ 739.0$; (IMF, 2012), and the avoidance of protectionist policies on the part of senior managers and super bonuses in TNC and TNB.

The fourth direction: To help financial institutions and selected industrial companies (with large size, market share weight in the national economy, but with problems in management identified during the crisis and a poor prognosis in the post-crisis period): support for the Central Bank liquidity of domestic financial institutions, including the entry of the state capital; nationalization (American mortgage company Freddie Mac, Fannie Mae, the Belgian bank Fortis); sale of bankrupt banks (Merrill Lynch buys Bank of America, respectively: Wachovia Citigroup, Washington Mutual Inc - JPMorgan Chase, Lehman Brothers - Barclays Plc, HBOS Plc - Loyds Bank, Bradford \& Bingley - Banco Santander); redemption of the state of bad debts; government subsidies, loans to industrial companies; state's acquisition of stakes in industrial companies; decline in interest rates (Japan up $0.1 \%$, the United States and Switzerland - 0.25\%, England - 0.5\%, Eurozone - 1.3\%, Australia - 3.25\%, Russia 10\%) (ECB: int / stats, 2013; ECB. Central Bank Exit Strategies. The Process Begins, 2010; ECB. int / press / key / date / 2012, sp 120907, sp 121008; ECB. int / press / key / date / 2013, sp 130212); suppression of inflation; carrying dangerous but saving to the crisis deflationary policy. 
The fifth line: Promote the transition to an economy of high technology and energy efficiency that can accelerate the recovery from the crisis and to form a new type of technological global economy.

Nationalization, buying by state distressed assets, the maintenance of employment and demand, social programs, government spending on the High-tech - classic Keynesian prescriptions. Tax benefits, the use of accounting and interest rates, avoiding inflation by controlling the money supply as instruments of monetary policy.

\subsection{Creeping Recession, New Phenomena and Laws of Global Finance (2010-2013)}

In 2012-2013 the world economy is still in the grip of the consequences of the global financial and economic crisis of 2008-2009. Despite the unprecedented crisis management monetary authorities G20, in the first decade of the twenty-first century have accumulated various risks and conflicts that hinder the final out of the crisis.

Firstly, in the world large imbalances between the developed and developing economies have developed the United States and the rest of the world, subcivilizations.

United States after the World War II was used as the world's reserve currency, receiving not only the "seigniorage" from the issue of dollars in the amount of \$ 500 billion. (Glazyev, 2013), but also "extra income" from issuing treasury bonds, ADR. All this allows the United States to use these revenues for additional benefits to the population, to ensure a higher quality of life compared to the rest of the world. And it is accompanied with three stable deficits - trade, payments and budget.

Great Britain, losing the status of a world power in the 30-ies of the twentieth century, has also been able to benefit from globalization, creating in 70-80 years. Twentieth century is extremely attractive for investors' world financial center of Eurocurrency, transactions, capital, secured thereby, the high standards of consumption and quality of life.

Scientific and practical interests are the anti-crisis actions of the FRS and the Treasury of the USA. They wore both emergency and long-term. By effective measures first direction we assign the reduction of money in circulation. In 2009-2011 annually 5.8-6.4 billion banknotes were produced against 9.1 billion in 2007. In 2012, the Treasury has increased the money supply to 8.4 billion, reflecting, on the one hand, the growth of demand and output out of recession, on the other - making money in a powerful tool for regulating the economy.

By the action of lagged effect is the program of "quantitative easing" (QE3), in force since 2008, and according to which the FRS bought Treasury bonds per month and mortgage-backed securities worth $\$ 85$ billion. According to this program, the FRS pays banks of the second level of the reserves at the rate IROR $0.25 \%$. With low rates of interest banks increased their reserves at the FRS, and the FRS liquidity and prepare for growth. Reserves, having instant liquidity, easily change in the currency, and the latter becomes a powerful tool of regulation of economic activity and inflation. Thus, the rate IROR, the quantity of reserves, short-term debt and the currency became stronger financial instruments of monetary policy of the USA in the crisis period.

July 10, 2013 Federal Reserve Open Market Committee (Federal open market committee - FOMC) confirmed the continuation of the quantitative parameters of monthly purchases of Treasury bonds and mortgage-backed securities worth $\$ 85$ billion, with a view to reach the unemployment rate of 7\% in middle of the 2014 (Yarding, 2013).

The second wave of risks was the result, as this thesis does not seem paradoxical, G20 anti-crisis programs and their effect. To stimulate economic growth (proposals from business and household demand) Federal Reserve conducted an additional issue of the dollar, and the Treasury has adopted the program of fiscal incentives. Additional issue of the United States in 2012 amounted to $\$ 58$ billion M1, M2 - \$74 billion. (ECB: int / stats, 2013), and fiscal stimulus in 2012 is estimated at $\$ 70$ billion. (Fiscal Year, 2013).

In general, actions of the monetary authorities of G20 for the first time in the history were solidarity and were unidirectional - providing liquidity to system creating banks, leading producers, the aggregate demand of the population, job retention, prevent inflation. Anti-crisis program in 2010 gave effect: acute phase of the recession has been passed, the fall in output and employment stopped. Central Bank of the world has managed to keep inflation by additional issue. But this tool of the control the money supply is dangerous because of the risk of loss of control over liquidity.

Serious risk in the post-crisis period represented growth of inflation. Central Bank of the leading economies of the world has managed to avoid it. By the end of 2012, inflation was $1.583 \%$ in the United States, the European Union - about 2, UK - 2.20, Germany - 2,152, Japan - (0.166\%) (Board of Governors of the Federal Reserve System. Financial Statement, 2011; Board of Governors of the Federal Reserve System (trends and forecast), 2012; Federal Reserve. newsevents / press, 2012; United States Department of the Treasury, 2013), as retained 
control over the money multiplier $(\mathrm{MM})$ in the range of $6-10 \%(\mathrm{MM}=\mathrm{M} / \mathrm{NR}$, where $\mathrm{MM}-$ Money Multiplayer; M - Money (M1 + M2); NR - Norms of Reserves (provisions)). In the group of BRICS inflation was higher: India - 12.98\%, Russia 6,708\%, Brazil - 4,968\%, China - 2,800\%. (International Monetary Fund, World Economic Outlook, 2012 by Information materials of the Ministry of Economic Development of the Russian Federation, 2012, China's macroeconomic data, in 2013, the Ministry of Finance of India, 2012) These economies less efficiently create money: in Russia the best MM in the pre-crisis years was not higher than 3\%, in China - 6\%.

Since 2008, the world economy has not yet recovered, did not come out lending to pre-crisis. At the same time, a new problem - the markets have lost market price targets. Stimulant actions of governments distorted picture of many commodity prices, especially on energy. The world economy has accumulated excess liquidity. Global investor invests in oil. But the rise in prices and holding them for 2012 at an average of $\$ 110$ / barrel of Brent (in the first half of 2013 the range was $\$ 98.38-108.82$ / bbl) was not a consequence of the growth in industrial production, and was the result of artificial support of banks, and hence financial markets of the Central Bank of the world.

An important factor for the world economy to come out of recession is to overcome the crisis in the United States and entry into the growth phase. In 2013, 3 anti-crisis programs continued to operate. They are "quantitative easing QEZ", "Sponsorship of debtor companies" (Government-sponsored enterprise debt securities), "Sponsorship of federal agencies and enterprises" through the purchase of mortgage-backed securities (Federal agency and Government-sponsored enterprise mortgage securities). The second and third program provides loans: companies for repayment of the debt in 2012, has been allocated \$ 80 billion (In 2011 \$108 billion), and for the redemption of "bad debts" on mortgage securities in 2012 was \$ 950 billion (In 2011 were $\$ 848$ billion) (IMF. Annual Report, 2012).

Despite the continued government injections into the economy, the markets begin to work as a regulator. From 1 May to 11 July 2013, all major indexes rose-market indicators: DJIA and S \& P at 4\%, Nasdaq - 6\%, the Russell 2000 of the small business by $10 \%$. Their rise reflects increasing economy, supported by historical statistics. There is a correlation between the growth rates on 10-year Treasury bonds and an increase in annual profits of the Fortune S \& P. Thus, over the period from 1962 to 2003 growth rates by 3.8 percentage points created the conditions for the growth of earnings per $10,8 \%$. For IQ 2013 growth rate was only $1.01 \%$ point, but it means that 7 out of 10 cases a year will rise in profits.

Apparently 2013 was a turning point for the economy of the United States: key economic indicators in the unemployment rate fell during the year from 7.8-7.9\% to 7\%. As a result, December 18, 2013 the FRS decided in principle to the beginning of the phasing out of the program of "quantitative easing" (QE): from January 2014 the FRS will buy at $\$ 40$ billion US T-bills and $\$ 35$ billion Mortgage bonds, so at $\$ 10$ billion less. Regulator chose the reduction of $\mathrm{QE}$ (the decline in the monthly repayment of assets) rather than tightening of monetary policy (so the increase in the base rate, which is in the range of $0-0.25 \%$ ). The market reacted to a minor correction and provoked the explosive growth of the yield of 10-year US Treasuries and debt in emerging markets.

Thus, the QE program has fulfilled its task - to facilitate the transition to economic growth. In 2014, it will be gradually phased out. From its continuing risks are greater than the benefits. At the same time employment growth rate will likely lower GDP growth. We believe that the $2 \%$ GDP growth is a good indicator for the transition to a new technological order.

If the reduction of QE by the market adequately, but the "P.Volker's Rule" (Paul Volker Role. P.Volker, the former head of the Federal Reserve) to ban "trading by banks' own funds" was not supported by the bankers. The law came into effect 21.07.2010 according to it with great powers of the Council to oversee the financial stability was created (Financial Stability Oversight Council FSOC). The Council has the right to demand an increase of capital and liquidity, limit the growth of large financial institutions (if they pose a threat to the financial system), and improved risk management. The law provides for measures to reduce banking risks, the protection of consumer financial services and regulation of activities of system creating banks.

P. Volker's rule, which is a part of the law, separates investment banking, private equity and hedge funds, financial institutions from consumer lending. Rule prohibits banks using government guarantees to invest depositors' funds in hedge funds and private equity funds in the amount of more than $3 \%$ of their Tier I capital (Tier I Capital), and hold more than 3\% of the capital of such funds. We believe that a return to some form of the Glass-Steagall Act (Glass-Steagall Act) reduce risky operations and improve the financial market of the USA. 
So, the future of the post-crisis global economy, the probability of a second wave of the crisis depends on overcoming imbalances (including, very importantly, household balance sheets), save the artificial support of the world economy by the Central Bank and the G20 governments. The faster the market return as a regulator of world prices than ever before in the United States, the United Kingdom, OECD countries recognize the need to avoid over-consumption on the background of trade and budget deficits, the faster the global economy overcome the consequences of the crisis, will find new sources of economic growth.

\subsection{EU - the Cradle of the Prolonged Recession and Still a Possible Second Wave of the Crisis}

State the total debt of the Latin countries before the crisis was above thresholds of $60 \%$ / GDP. But these countries have not reduced consumption, and government low spending.

As a result, in 2008-2012 Greece, unable to cope with the debt burden, was constantly on the verge of financial bankruptcy. To the governments of southern Europe emerged an alternative: either - default, the financial collapse, the bankruptcy of the monetary authorities, the launch of the second wave of the flywheel of the global crisis, a smooth departure from imbalances and gradual recovery from the crisis.

All these years, markets with a spread of 400-3250 bp lent Greece, Spain, Portugal and Italy. But the credit market opportunities and risks are to the limit, as the Latin countries cannot service the debt on market conditions no longer, and the ability of Germany to lend to the European Central Bank (ECB) is also limited.

As the markets have exhausted their resource potential, the monetary authorities of the EU made four unprecedented step, incrementally using various financial instruments.

The first step was taken in 2008 in the money market. Latin countries were granted loans totaling 1.2 trillion euro. The effect was negative. Markets reacted with increasing spreads of 80 basis points (bps) in July 2007 (12 months above Libor, euros) to 120 bps in October 2008 (Halpenny, 2010).

The second step was taken primarily by the efforts of the central banks of the EU on the market for government debt. Chronology of anti-crisis measures of the monetary authorities of the EU: July 4, 2009 program began buying government bonds of troubled countries; May 10, 2010 EU central banks have begun to purchase securities under the Securities Market Program (SMP); October 6, 2011 a new program of bond purchases (CBPP2). Market reaction was negative. Spreads on sovereign debt of Belgium increased from $150 \mathrm{bp}$ in October 2011 (the maturity of 10 years, Index - sovereign bond yields in Germany, bps) to 200 bps in July 2012, respectively, in France from 90 to 200, Italy 380 vs 420, Greece 2100 vs 2800 (European Commission on Enterprise and Industry and Finance, 2012; ECB: Financial Stability Review, 2012; ECB: Financial markets and global financial institutions, 2012; Markets Data, 2013).

The third step - in the "battle" cast a last EU reserve - ECB lender of last resort. In the autumn of 2012 the ECB started buying government bonds of troubled countries. Now the liquidity of these securities became dependent on the ECB, not the markets and the national central banks. Investors and rating agencies reacted positively to these actions of the EU regulator. Yields on sovereign debt has stabilized and differentiated segment of the global financial market: Germany, France, Belgium, UK, USA, Japan (range 0-2\% per annum); Spain, Brazil, China (5.3\% pa), Portugal, Russia (10.5\% per annum), and finally, Greece - $15 \%$ or more. (Geography of the crisis, in 2013).

Presented differentiation reflects a range of macroeconomic factors: GDP growth, inflation and unemployment, deficit/ surplus of the trade balance, balance of payments, the budget, the ratio of public debt / GDP ratio, eventually - the sovereign credit rating, etc.

The fourth step was taken at the turn of 2012-2013: in September 2012, Vice-President of the ECB proposed to create a single banking union. It is certainly not about the union of the existing 6000 credit institutions and systemic banks, which implies uniform standards of ECB control procedures, insurance funds 60 billion euro and the Russian equivalent of 1998 ARCO. In December, an idea was supported by the Board of the ECB, and in February 2013 was agreed upon a plan of gradual formation of the Fund and Bank Union (ECB. Int / press / key / date / 2012, sp 120907, sp 121008; ECB. Int / press / key / date / 2013, sp 130212). However, the European Commission's plan ran into serious legal problems (Peel \& Barker, 2013).

For the final salvation of the EU and the euro there is a need in the fifth step - the creation of a unified budget of the Euro zone. But it is a question of loss EU member states fiscal sovereignty. Denial of financial independence EU member states prefer likely to create TAFTA (TAFTA - Trans Atlantic Free Trade Agreement), which has been negotiated in Washington in July 2013. 
So, the future of the EU and the euro depends on the rate of economic growth. But the EU is still in recession. Problems of economic growth of the EU have not been solved not because of the national debt of the Latin countries. The latter circumstance - superficial causes of the crisis. Its nature is due to two factors.

First, the difficulties of the transition of the European economy to the new technological order, the new economy of the XXI century. Germany and France, burdened with the problems of the Eurozone and the euro rescue, do not act as the leader of the "new wave of technology." From this point of view, the European economy may be only the fifth after the United States, China, Japan and South Korea in the XXI century.

Secondly, the EU is not bridged the gap in quality of life between the north and south of Europe. Its basis is a significant difference in the level of productivity of labor, management, labor skills and vocational education. This undermines the value of the euro, which was created in the south and the north, provokes politicians and unions Latin countries to the slogan of establishing a single hourly wages and the same welfare system.

\section{Discussion}

Global science rather comprehensively, comprehensively analyzed the causes, propagation mechanisms, the effects of anti-crisis measures and the monetary authorities of the first global finance crisis in Mexico (Osokina, 1998; Obstfeld, 1994; Ozkan \& Sutherland, 1995), the Southeast Asian countries (Menshikov, 1998; Burnside et al., 2000; Shavshukov, 2001; Allen \& Gale, 2000; Demirguc-Kunt, 1998; Hunter et al., 1999; Krugman), Russia (Gaidar \& Chubais, 2011 by an Interim Committee of the Council Federatsii1998 g.; Luntovsky and Zaitsev, 1999; Shavshukov, 2001; Shokhin \& Zhuravlev, 1999), the global economy, 2008-2009. (Attali, 2009; Buzgalin \& Linke, 2010, Lewis, 2011 by the global financial crisis and the economic security of Russia, in 2010, the world financial system after the crisis of 2009, Soros, 2009; Rogowski \& Vasiliev, 2008; Stiglitz, 2012). Studies have shown that if the Mexican crisis came with the currency market, in the Southeast Asian countries the reasons are related to industrial overproduction. The Russian crisis of 1998 revealed itself as a debt, banking. The global crisis of 2008-2009 considered in science, mainly at the level of analysis of the collapse of the mortgage market and the United States anti-crisis measures of the monetary authorities.

Despite the fact that the nature of global crises was examined by Nobel Peace Prize P. Krugman (the Asian crisis in 1997), Yu. Hama, Dzh. Stiglits (global crisis of 2008-2009), The Swedish state-owned bank Prize in Economic Sciences in Memory of Alfred Nobel never awarded for the research on the global economy, global finance, global crises.

\section{Conclusions}

Crises of the global economy (1994-2014) enriched the theory and practice of anti-crisis policy of the monetary authorities by new phenomena and laws. Let us highlight some of them.

1. Cradle of crisis processes was at different times in different national economies (SEA countries in 1997, USA in 2008). Inflation news, the balance of payments deficit, binding to the anchor currency, the lack of international liquidity of the Central Bank, the weakness of the banking system worked on the crisis. Leaving of global investors, withdrawal of the capital aggravated the economic situation.

2. The global crisis of 2008-2009 demonstrates a truly global reach for the first time, solidarity and unidirectional anti-crisis actions of G20: financing of infrastructure projects, stimulation of consumer demand through tax breaks and lower rates on loans, the reform of the Bretton Woods institutions, help of the strategic financial institutions, promoting the transition to a high-tech economy.

The crisis sharply raised the question of new sources of growth for the world economy. Roadmap of their solution lies on two levels of analysis: the surface causes of the crisis (financial collapse in the United States) and its deep nature (transition to a new technological order) and in the following areas: addressing the problems of civilization of mankind as a new source of economic growth in the global economy, changes in the architecture of the global economy (an adequate reflection of the emerging economies in the international monetary system, international financial institutions, the strengthening of regional organizations (ASEAN, BRICS, Mercosur, etc.).

1. Flaccid recession in developed economies in 2009-2013 revealed major imbalances in the global economy and allowed to hone tactical tools of anti-crisis measures of the monetary authorities. In 2012, the FRS and the ECB have used powerful tools - an additional issue of the dollar and the purchase of government debt of troubled EU economies. First, it became apparent that the anti-crisis programs regulators may mislead markets. To the national economic imbalances (trade, budget, payments deficits) were added intraregional (EU) and global (between the United States, the countries of the OECD and the rest of the world, subcivilizations). 
2. The anti-crisis measures were a combination of Keynesian and monetarist prescriptions. The first are nationalization, purchase by state (or regional financial institutions - RFI) distressed assets, the maintenance of employment and demand, social programs, public spending on High-tech. The second are tax breaks, reducing rates of discount and rates of interest, avoiding inflation by controlling the money supply.

3. In the anti-crisis policy of the monetary authorities the general and particular is traced. Common in government policies and the Central Bank were: increase in rates of interest on government bonds, devaluation, debt restructuring and sponsoring companies on a national scale, loans from the Central Bank and the IMF, public investment in infrastructure projects, solving the global crisis and the search for mechanisms of economic growth through regional associations (EU, ASEAN, NAFTA).

To the special we put debt restructuring of small and medium-sized enterprises, the privatization of infrastructure industries, transfer of public debt in dollars (Mexico), increase in the share of the state (or increased regulation) in the banking sector and restructuring of the banking system (Malaysia, Russia, the United States), stimulation of the transition to a new technological type of economy (the United States, France, Russia, South Korea).

At the turn of the centuries it is necessary to solve the civilizational problems of humanity (environment, food, water, alternative energy sources, poverty) and its transition to a new type of production, based on genetic engineering, information, nano - and other green, blue technology. Finding new sources of development and growth of the world economy is related to this.

\section{References}

Allen, F., \& Gale, F. (2000). Bubbles and Crises. Economic Journal, 110, 236-255. http://dx.doi.org/10.1111/ 1468-0297.00499

Annual Report 2012. IMF. Retrieved June 27, 2013, from http://www.IMF.org/externak/russian/pubs/ft/2012/ ar12rus.pdf

Attali, J. (2009). The global economic crisis ... What's next? St. Peter.

Bank of England. Main Publications. Retrieved January 27, 2013, from http://www.bankofengland.co.uk/publica tions/PublishingImages/inflationreport/cpimktfeb13large.gif; http:/www.bankofengland.co.uk/publications/ Pages/main/default.aspx

Board of Governors of the Federal Reserve System (trends and forecast). Minutes of the Federal Open Market Committee. (n. d.). FRB: Summary of Economic Projections. Retrieved January 27, 2013, from $\mathrm{http}: / / \mathrm{www}$. federalreserve.gov/monetarypolicy/fomcminutes20121212ep.htm

Burnside, C., Eichenbaum, M., \& Rebelo, S. (2000). Prospective Deficits and Asian Currency Crisis. World Bank Working Paper, 2174 (in the Agriculture Land, Commodity prices, Market series). http://dx.doi.org/10.1596/1813-9450-2174

Buzgalin, A., \& Linke, P. (2010). Crisis alternatives for the future: An Anthology (p. 368). Moscow: Cultural Revolution.

China's macroeconomic data. Retrieved June 27, 2013, from http://www.news.xinhua08.com/zt/jjsj/201302/ \#f-0382

Cœuré, B. (Member of the Executive Board of the ECB). (2012, October 8). Why the euro needs a banking union. Conference "Bank funding - markets, instruments and implications for corporate lending and the real economy”. Frankfurt am Main. Retrieved January 27, 2013, from http://www.ecb.int/press/key/date/ 2012/html/sp121008_1.en.html

Conclusion-hoc committee of the Federation Council to investigate the causes, circumstances and consequences of the default of 1998. Retrieved June 27, 2013, from http://www.glazev.ru/econom_polit/23/

Constâncio, V. (Vice-President of the ECB). (2012, September 7). Towards a European Banking Union. Lecture held at the start of the academic year of the Duisenberg School of Finance, Amsterdam. Retrieved January 27, 2013, from http://www.ecb.int/press/key/date/2012/html/sp120907.en.html

Constâncio, V. (Vice-President of the ECB). (2013, February 12). Towards the Banking Union. 2nd FIN-FSA Conference on EU Regulation and Supervision "Banking and Supervision under Transformation". Lecture conducted from Financial Supervisory Authority, Helsinki. Retrieved January 27, 2013, from http://www.ecb.int/press/key/date/2013/html/sp130212.en.html

Demirguc-Kunt, Detragiache, Asly, \& Enrica. (1998) The Determinants of Banking Crises in Developing and Developed countries. IMF Staff Papers, 45, 81-109. 
ECB: Financial Stability Review. Retrieved January 27, 2013, from http://www.ecb.int/pub/fsr/shared/pdf/ iii3financialstabilityreview201206en.pdf?2c9941d09e56638c0669816c854ad384

Financial markets and global financial institutions. (2012, December). European Central Bank. Retrieved January 27, 2013, from http://www.ecb.int/pub/fsr/shared/pdf/3financialstabilityreview201212en.pdf?a9a 4207de2e406c98f944fbd4a842268

Fiscal Year 2013. Mid-session Review. Budget of United States Government. Retrieved June 27, 2013, from http://www.IMF.org/externak/russian/pubs/ft/2012/ar12rus.pdf.www.omb.gov

Gaidar, E. T., \& Chubais, A. B. (2011). Fork in the recent history of Russia (p. 168). St.: Norma.

Geography crisis. (2013, May 23). Kommersant. Retrieved June 27, 2013, from http://www.kommersant.ru/doc/ 2185521

Glazyev, S. Y. (n. d.). Military and political hegemony of the United States is largely held by the issuance of the dollar as the world reserve currency and global assignment of seigniorage, the size of which is about half a trillion dollars a year. Retrieved June 27, 2013, from http://www.glazev.ru/econom_polit/

Halpenny, D. (2010, March). Central Bank Exit Strategies. The Process Begins. Retrieved January 27, 2013, from http://www.ecb.int/paym/groups/pdf/fxcg/exit_strat_march_2010_botm.pdf?8a4d02aada243b0bcd47c b2cae62ac57

Hunter, W., Kaufman, G., \& Kruger, T. (1999). The Asian financial crises, origins, implications and solutions. Boston.

Information materials of the Ministry of Economic Development of the Russian Federation. Social and Economic Development of the Russian Federation for 2013-2015. (2012, December 14). Retrieved June 27, 2013 from http://www.economy.gov.ru/minec/activity/sectio ns / macro / prognoz / doc20121214_02

International Monetary Fund, World Economic Outlook Database, October 2012. Retrieved June 27, 2013, from http://www.IMF.org/externak/russian/pubs/ft/2012/ar12rus.pdf.imf.org/external/pubs/ft/weo/2012/02/weoda ta/download.aspx

Krugman, P. (2012). What happened in Asia? Retrieved June 27, 2013, from http://www.IMF.org/externak/ russian/pubs/ft/2012/ar12rus.pdf.www.hartford-hwp.com/archives/50/010.html

Lewis, M. (2011). A great game for a fall. Secret springs of financial disaster (p. 288). Moscow: Alpina Publisher.

Loans. European Commission on Enterprise and Industry and Finance. Retrieved January 27, 2013, from $\mathrm{http} / /$ www.ec.europa.eu/enterprise/policies/finance/data/enterprise-finance-index/access-to-finance-indicat ors/loans/index_en.htm

Luntovsky, G. A., \& Zaitseva, Z. Z. (1999). Procedural problems bankruptcy of Russian commercial banks. Economic nauki, 1, 76 -77.

Markets Data. (2013, July 11). Financial Times. Retrieved January 27, 2013, from http://markets.ft.com/research/markets/overview

Menshikov, S. (1998). Asian financial crisis and the global economy. Problems of the theory and practice of management, 2, 40-44.

Ministry of Finance India. Retrieved June 27, 2013, from http://www.finmin.nic.in/stats_data/nsdp_sdds/index. $\mathrm{html}$

Minutes of the Federal Open Market Committee. (2012). Federal Reserve. Retrieved January 27, 2013, from http://www.federalreserve.gov/newsevents/press/monetary/fomcminutes20121212.pdf

Money Stock Measures. Federal Reserve statistical release. (2013, October, 17). Board of Governors of the Federal Reserve System. Retrieved January 27, 2014, from http://www.federalreserve.gov/releases/h6/ current/h6.htm

Obstfeld, M. (1994). The logic of currency crises. Cahiers Economiques et Monetaires, 43, 189-213.

Osokina, N. (1998). Mexican economic crisis in 1994. Observer, 10. Retrieved January 27, 2013, from http://www.rau.su/observer/№10_98/10_13 HTM

Ozkan, F. (1995). Policy Measures to avoid a currency crises. Economic Journal, 105, 510-519.

Peel, Q., \& Barker, A. (2013, July 11). Berlin hits at banking Union Plan. Financial Times, P2. 
Rogowski, E. A., \& Vasilyev, V. S. (2008). Global economy and the factor Greenspan. The United States and Canada: the economy, politics, culture, 11.

Shavshukov, V. M. (2001). Formation of the Russian segment of global finance (p. 368). St. Petersburg.

Shokhin, A. N., \& Zhuravlev, S. N. (1999). Financial and economic crisis, causes and measures to resolve. Economics, 1, 15-26.

Soros, G. (2010). The first wave of the global financial crisis: the subtotals. New Paradigm for Financial Markets (p. 272). Moscow: Mann, Ivanov and Ferber.

Stiglitz, J. (2012). On the international monetary and financial system: lessons from the global crisis. Report of the Finance Committee of the United Nations (p. 328). Moscow: International Relations.

The global financial crisis and the economic security of Russia: Analysis, Problems and Prospects (p. 208). (2010). Moscow: Economy.

The global financial system after the crisis: assessment and forecasts (p. 220). (2009). Moscow: Maroseyka.

Treasury of UK. Retrieved June 27, 2013, from http://www.hm-treasurygov.uk/int-g7-intervention.htm

United States Department of the Treasury. Retrieved June 27, 2013, from http://www.treasury.gov/resoursecenter/data-chart-center/monitoring-theeconomy/Documents/monthly\%20ECONOMIC\%20DATA\%TABL ES.pdf

World retribution for crisis. (2009, August 3) Finmarket. Retrieved June 27, 2013 from http://www.finmarket. $\mathrm{ru} / \mathrm{z} / \mathrm{nws} /$ hotnews.asp?id=1241109\&rid=1

Yarding, R. (2013, July 11). Slowing of Fed`s QE3 remains in balance. Financial Times, P1.

\section{Copyrights}

Copyright for this article is retained by the author(s), with first publication rights granted to the journal.

This is an open-access article distributed under the terms and conditions of the Creative Commons Attribution license (http://creativecommons.org/licenses/by/3.0/). 